\title{
PRODUCTION OF SCENEDESMUS DIMORPHUS GROWN ON SOME WASTES (POULTRY MANURE) USED IN AQUACULTURE
}

\author{
Tartiel El-Sayed Mohamed Badawy \\ Central Laboratory for Aquaculture Research, Abbassa, Ecology and Biology \\ Department, Agricultural Research Center, Ministry of Agriculture, Cairo, Egypt.
}

\begin{abstract}
As compared to Bold's basal medium (B.B.M.), high yields of Scenedesmus dimorphus in terms of cell number, protein, chlorophyll "a" and algal dry weight contents were achieved at low concentrations of poultry manure water extract $(0.2 \%-0.6 \%)$. Cell diameter and dry weight increased with increasing waste concentration. Nucleic acid contents of Scenedesmus dimorphus grown on poultry manure were lower than that values obtained when the alga was grown on Bold's basal medium (B.B.M.). A well balanced distribution of protein amino acids was found in Scenedesmus dimorphus grown on water extract of poultry manure, which was comparable with that of FAO reference protein. Also it was found that such protein had a chemical score of 61.1 while the protein of Scenedesmus dimorphus grown on Bold's basal medium had a chemical score, which equals 47.4.

Key words: Bold's basal medium, poultry manure, protein high nutritive. Scenedesmus dimorphus.
\end{abstract}

\section{Introduction}

Since the world is alarmed by the population explosion and food crisis, one may ask whether there is any sense today in looking for non-conventional sources of protein for animal and possibly, human nutrition? Indeed protein is a vitally important food material required by man (Fathy and Seyam, 1989 and De Pauw et al., 1998). The use of microalgae in aquaculture has several potential advantages over the production of microalgae for human foods or terrestrial animal feeds such as high conversions efficiencies and no need for harvesting, drying and storage as the animals or food chains could use the algae as produced (Allen and Nelson, 1974; Benemann, 1992).

Out of the intensive research in many countries, one can conclude that, microalgae provide a valuable source of protein and other chemical compounds (Becker, 1994). High productivity of microalgae is only achieved in tropical or subtropical countries, where the climatic conditions favor continuous cultivation all year round. Microalgae may provide such countries with a potential direct and indirect protein source which can be locally produced. In the commercial and semi-commercial production of algae for feed and food, important advances have 
been made in South East Asia (Saleh et al., 1979; Zaret et al., 2001 and Persoone et al., 2002).

For biologists, algae offer a number of distinct advantages. In addition to being photosynthetic autotrophs unicellular algae posses a number of microbial characteristics including rapid growth rate, high protein content and variable metabolism, which respond rapidly to environmental changes. Some studies have been carried out to investigate the chemical composition of microalgae. Microalgae are rich in vitamins and fats, also their protein quality, in terms of the amounts of important amino acids are high. Badawy (2005) found that crude protein content of Chlorella spp. was $46.7 \%$, the crude fat content was $14.8 \%$, total carbohydrate content was $11.6 \%$, ash was $17.5 \%$, crude fiber was $9.30 \%$, nucleic acid content (RNA $2.63 \%$ and DNA $1.72 \%$ ), and vitamins group antioxidant $\mathrm{B}_{6}, \mathrm{~B}_{12}, \mathrm{E}, \mathrm{C}, \mathrm{B}$-carotene $(\mu \mathrm{g} / \mathrm{g}$ dry weight) were found to be 0.05 , $0.08,2.25,16.0$ and 2384.0, respectively. Meanwhile, Scenedesmus spp. contained $52.3 \%$ crude protein, $12.20 \%$ crude fat, $10.06 \%$ Carbohydrate, 14.92 $\%$ ash, $8.83 \%$ crude fiber, $3.16 \mathrm{RNA}$ and $1.43 \mathrm{DNA}, 0.27 \mathrm{~B}_{6}, 0.78 \mathrm{~B}_{12}, 0.01 \mathrm{E}$, $21.8 \mathrm{C}$ and $1890.0 ß$-carotene ( $\mu \mathrm{g} \backslash \mathrm{g}$ dry weight). El-Fouly et al. (1984) reported that, five amino acids (aspartic acid, serine, alanine, leucine and glycine) were collectively responsible for $50 \%$ or more of the total dry matter content of Chlorella and Scenedesmus algae, However, they were deficient in sulfur-amino acids. Natural food still remains the major feed for Tilapia rearing so a timely supply of microalgae in sufficient quantity ensures the success of a tilapia hatchery. Microalgae and cyanobacteria grown on wastes can be used as a dietary supplement for animals and for any other biotechnological purposes.

Recycling of poultry manure and evaluation of Scenedesmus dimorphus grown on it is the aim of the present study. The present study was carried out in the Central Laboratory for Aquaculture Research (CLAR) and International Central Laboratory for Aquaculture Research Management. The World Fish Center, Regional Center for Africa and West Asia, Abbassa, Abu-Hammad, Sharkia, Egypt.

\section{Materials and Methods}

\section{Algal strain and Nutrient solution:}

A pure strain of Scenedesmus dimorphus were obtained from the Department of Botany, National Research Center, Dokki, Cairo, Egypt. The inoculum was prepared in laboratory, $250 \mathrm{ml}$ Erlenmeyer flasks each containing $100 \mathrm{ml}$ of sterilized media was inoculated with Scenedesmus dimorphus in a concentration of $1.5 \times 10^{6} \mathrm{cells} / \mathrm{ml}$. The control medium (nutrient standard solutions) Bold's basal medium (B.B.M.) according to Bischoff and Bold (1963). B.B.M. composition is illustrated in Table (1). Algae cultures were incubated in the growth room at $25{ }^{\circ} \mathrm{C}$, adjusted by air condition, continuous illumination 
provided by 6 fluorescent lamps which gave a light intensity of 5000 Lux, under photoperiods $16 \mathrm{~h}$ light/ $8 \mathrm{~h}$ dark cycle. The $\mathrm{pH}$ was adjusted daily to 8.0; fluorescent lamps as well as photoperiods were adjusted by electricity timer.

Table (1): Chemical composition of B.B.M. medium

\begin{tabular}{|c|c|}
\hline Chemicals & $\begin{array}{c}\text { Final } \\
\text { concentration }\end{array}$ \\
\hline $\begin{array}{l}\text { A. Macronutrients: } \\
\text { Consist of six stock solutions: }\end{array}$ & \\
\hline 1-Sodium nitrate $\left(\mathrm{NaNO}_{3}\right)$ & $25 \mathrm{~g} / \mathrm{L}$ \\
\hline $\begin{array}{l}\text { 2- Potassium dihydrogen phosphate } \\
\left(\mathrm{KH}_{2} \mathrm{PO}_{4}\right)\end{array}$ & $17.5 \mathrm{~g} / \mathrm{L}$ \\
\hline $\begin{array}{l}\text { 3-Dipotassium hydrogen phosphate } \\
\left(\mathrm{K}_{2} \mathrm{H}_{2} \mathrm{PO}_{4}\right)\end{array}$ & $7.5 \mathrm{~g} / \mathrm{L}$ \\
\hline 4-Magnesium sulfate $\left(\mathrm{MgSO}_{4}\right)$ & $7.5 \mathrm{~g} / \mathrm{L}$ \\
\hline 5-Calcium chloride $\left(\mathrm{CaCl}_{2}\right)$ & $2.5 \mathrm{~g} / \mathrm{L}$ \\
\hline 6-Sodium chloride $\left(\mathrm{NaCl}_{2}\right)$ & $2.5 \mathrm{~g} / \mathrm{L}$ \\
\hline $\begin{array}{l}\text { B. Micronutrients: } \\
\text { Consist of four stock solution: }\end{array}$ & \\
\hline $1-\mathrm{Na}_{2}-\mathrm{EDTA}+\mathrm{KOH}$ & $50 \mathrm{~g}$ plus $31 \mathrm{~g} / \mathrm{L}$ \\
\hline $2-\mathrm{FeSO}_{4} .7 \mathrm{H}_{2} \mathrm{O}$ & $4.98 \mathrm{~g} / \mathrm{L}$ \\
\hline 3- $\mathrm{H}_{3} \mathrm{BO}_{3}$ Boric acid & $11.42 \mathrm{~g} / \mathrm{L}$ \\
\hline $\begin{array}{l}\text { 4-The following four salts: } \\
\text { All were dissolved in one liter of distilled water. }\end{array}$ & \\
\hline$-\mathrm{ZnSO}_{4} \cdot 7 \mathrm{H}_{2} \mathrm{O}$ & $8.82 \mathrm{~g} / \mathrm{L}$ \\
\hline$-\mathrm{MnCl}_{2}$ & $1.44 \mathrm{~g} / \mathrm{L}$ \\
\hline$-\mathrm{CuSO}_{4}$ & $1.57 \mathrm{~g} / \mathrm{L}$ \\
\hline$-\mathrm{Co}\left(\mathrm{NO}_{3}\right)_{2} \cdot 6 \mathrm{H}_{2} \mathrm{O}$ & $0.49 \mathrm{~g} / \mathrm{L}$ \\
\hline
\end{tabular}

To prepare one liter of Bold's basal medium added $10 \mathrm{ml}$ of each six stock solution (macroelements) and $1 \mathrm{ml}$ of each four stock solution (microelements) and add $936 \mathrm{ml}$ distilled water. Macronutrient consists of six stock solutions as well as micronutrient consists of four stock solutions, each amount of salts is dissolved separately in $100 \mathrm{ml}$ warm water and diluted into one liter distilled water.

\section{Extraction of waste:}

Poultry manure samples were randomly collected in polyethelene bags. The samples were air-dried in the laboratory for 5 weeks. Three equal samples of the air dried poultry manure were ground (by a mortar and pestle) for homogencity and to facilitate extraction. They were extracted with equal volumes of distilled water (each $200 \mathrm{ml}$ ) for $20 \mathrm{~min}$. at different temperatures $\left(22^{\circ} \mathrm{C}, 100^{\circ} \mathrm{C}\right.$ and $120^{\circ} \mathrm{C}$ ). The supernatant extracts were obtained by centrifugation at 7000 r.p.m. 
for $20 \mathrm{~min}$. From each extract six different concentrations $(0.2 \%, 0.4 \%, 0.6 \%$ \& $1.2 \%$ concerning the solid waste) were prepared by dilution using distilled water. The $\mathrm{pH}$ of each trial was adjusted at 8.0 using diluted HCL or $\mathrm{NaOH}$ solution. Results of the chemical analysis of poultry manure are shown in Table (2). To study utilization of waste constituents by Scenedesmus dimorphus two sets of culture flasks (each contained $100 \mathrm{ml} 0.4 \%$ sterilized poultry manure $\mathrm{pH}$ 8.0) were prepared. The first set of flasks was inoculated by Scenedesmus dimorphus in a concentration of $1.5 \times 10^{6}$ cells $/ \mathrm{ml}$ under aseptic conditions. The second set of flasks (control) was left without inoculation. Both sets were incubated for 4 days, at the end of which the final $\mathrm{pH}$ was determined. The growth (number of cells $/ \mathrm{ml}$ ) was measured and the contents of flasks of both sets were centrifuged (7000 rpm for $15 \mathrm{~min}$ ). The supernatants were analyzed for soluble carbohydrates, nitrate, free ammonia and amino acids.

Table (2): Chemical analyses of poultry manure (\% D.M basis)

\begin{tabular}{|l|c|}
\hline \multicolumn{1}{|c|}{ Item } & Poultry manure \\
\hline Crude protein (CP) & 26.5 \\
Crude fiber (CF) & 15.9 \\
Nitrogen free extract (NFE) & $\mathbf{2 5 . 4}$ \\
Ether extract (EE) & $\mathbf{2 . 2 0}$ \\
Ash matter (DM) & $\mathbf{3 0 . 0}$ \\
Dry matter & $\mathbf{8 4 . 7}$ \\
Moisture & $\mathbf{1 3 . 3}$ \\
\hline
\end{tabular}

\section{Chemical analysis:}

The following analysis were carried out: total nitrogen (APHA, 1985), (the crude protein content was calculated as total nitrogen content $\mathrm{x} 6.25$ ), ether extract, crude fiber, ash and moisture (A.O.A.C. 1995), cell of Scenedesmus dimorphus were harvested by centrifugation at 7000 r.p.m., chlorophyll "a" content was measured spectrophotometricaly according to (Vollenweider 1969 \& APHA, 1985). Nucleic acids were determined according to Morse and Carter (1969). To determine the algal dry weight, samples were oven dried at $60-65^{\circ} \mathrm{C}$ for $72 \mathrm{hr}$. up to constant dry weight.

\section{Results and Discussion}

The ranges obtained in this investigation for microalgae protein production were similar to the values reported by other authors (Flaak and Epifanio, 1978; El-Fouly et al., 1979; Becker, 1994). Water extracts of poultry manure supported excellent algal growth when compared with the control medium (B.B.M.) especially with low concentrations $(0.2 \%, 0.4 \%$ and $0.6 \%)$ whatever the extraction temperature. However, the algal growth which was obtained at $0.4 \%$ (optimum) chicken manure extracted at $22{ }^{\circ} \mathrm{C}$ was found to be 
higher than that at $100{ }^{\circ} \mathrm{C}$ and $120{ }^{\circ} \mathrm{C}$ (Figures 1, 2 and 3). These results are in agreement with those of Becker (1987); Allen and Garret (1977); El-Fouly et al., (1998).

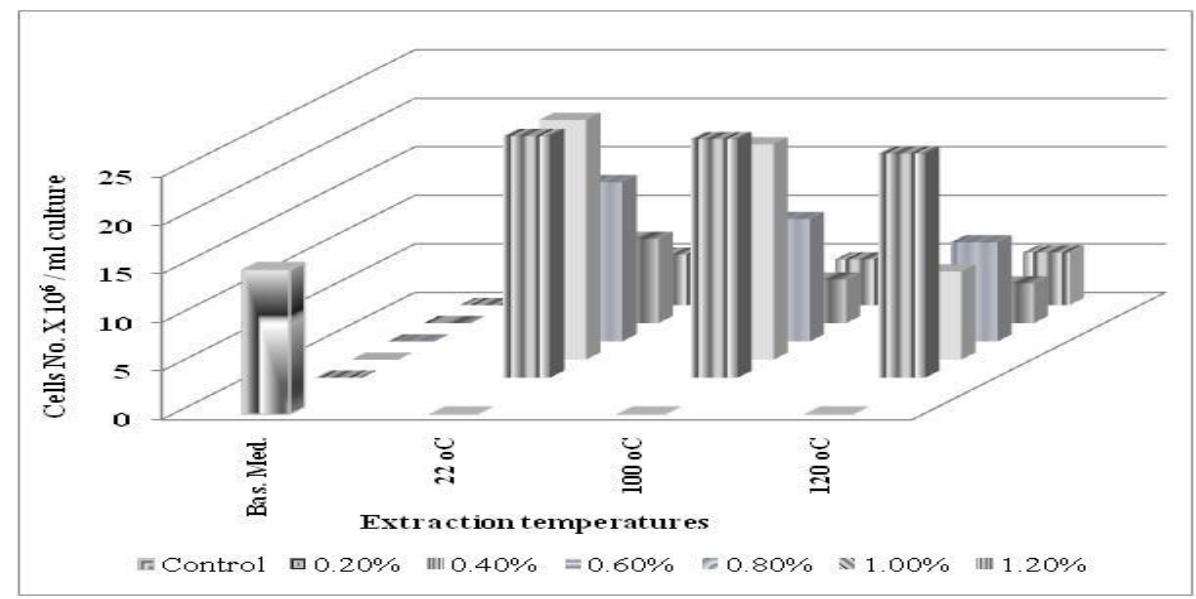

Figure (1): The growth of Scenedesmus dimorphus grown on Bold's basal medium and different concentration of poultry manure extracted at different temperatures

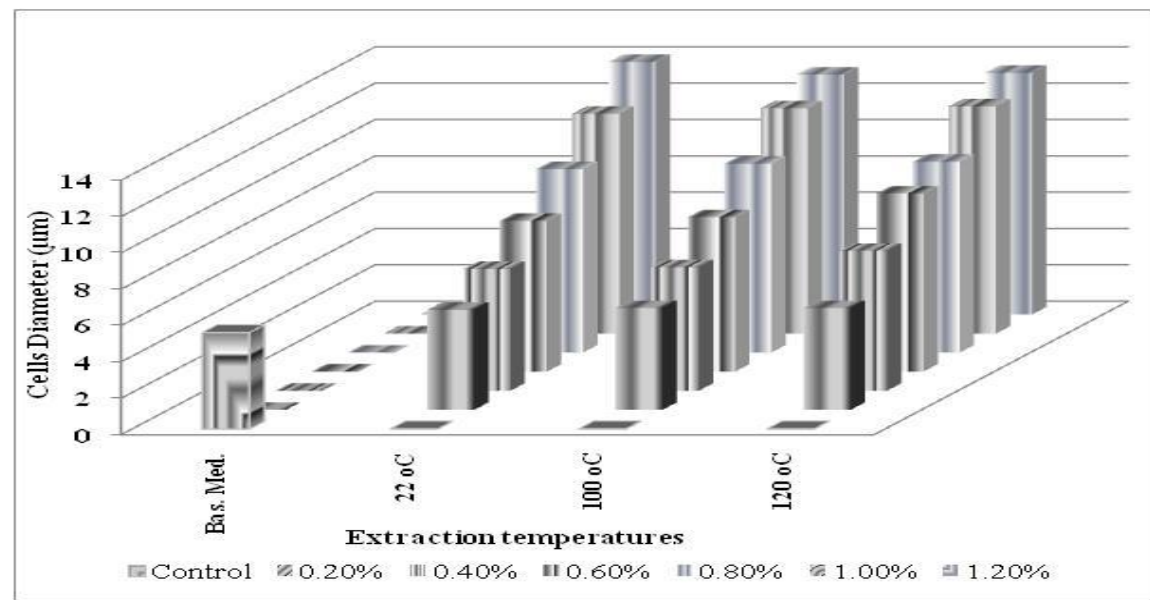

Figure (2): The cell diameter of Scenedesmus dimorphus grown on Bold's basal medium and different concentration of poultry manure extracted at different temperatures

Where high concentrations of wastes extracted at high temperatures decreased the algal growth. These results indicate that a temperature of $22^{\circ} \mathrm{C}$ may account for the release of essential nutrients and growth promoting compounds. 
Higher temperature may produce growth delimiting compounds. The cell volume and the algal dry weight (Figs. 2 and 4) were clearly varied.

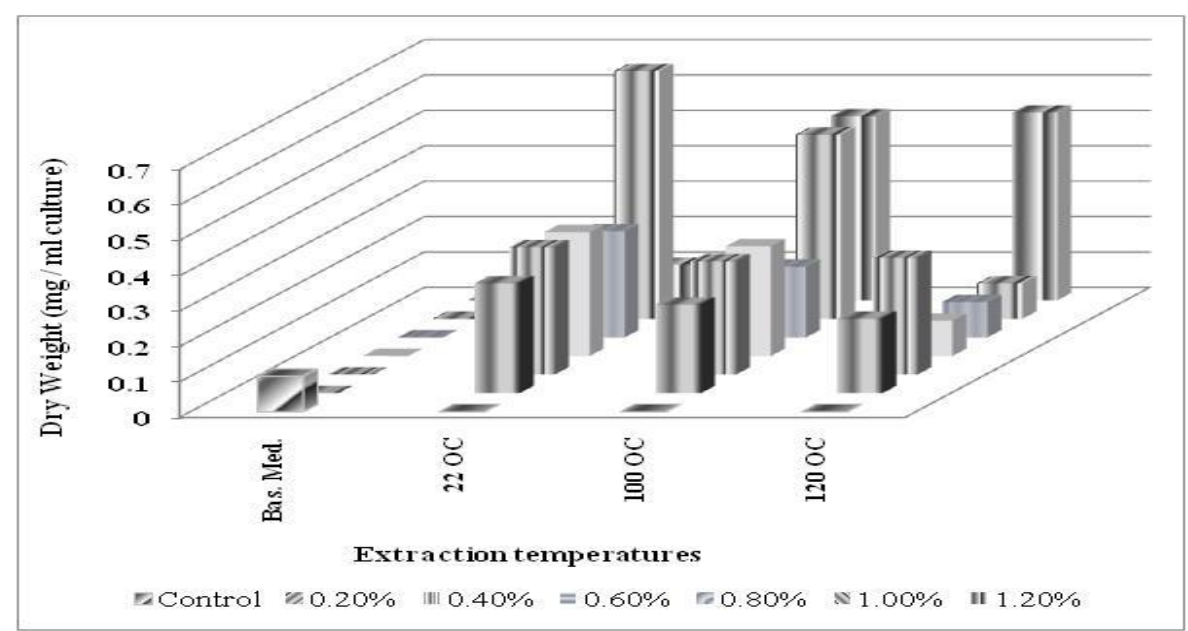

Figure (3): Dry weight of Scenedesmus dimorphus grown on Bold's basal medium and different concentration of poultry manure extracted at different temperatures

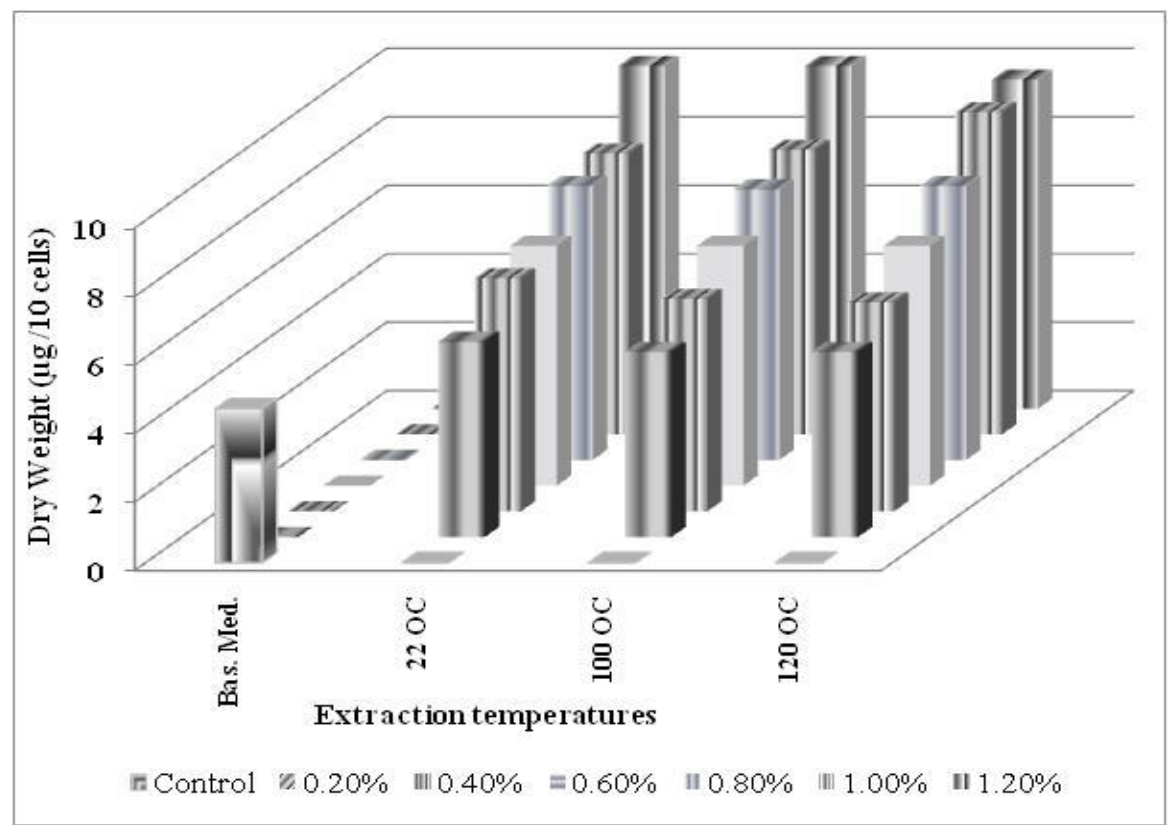

Figure (4): Dry weight of Scenedesmus dimorphus grown on Bold's basal medium and different concentration of poultry manure extracted at different temperatures 
The algal cells grown on the basal medium attained the smallest volume compared to those grown on the waste extracts. As shown from figure 5, the maximum growth rate of Scenedesmus dimorphus was achieved after 4 days on $0.4 \%$ waste concentration. Therefore, the incubation period for all culture experiments subjected to biochemical analysis were conducted for 4 days using $0.4 \%$ waste.

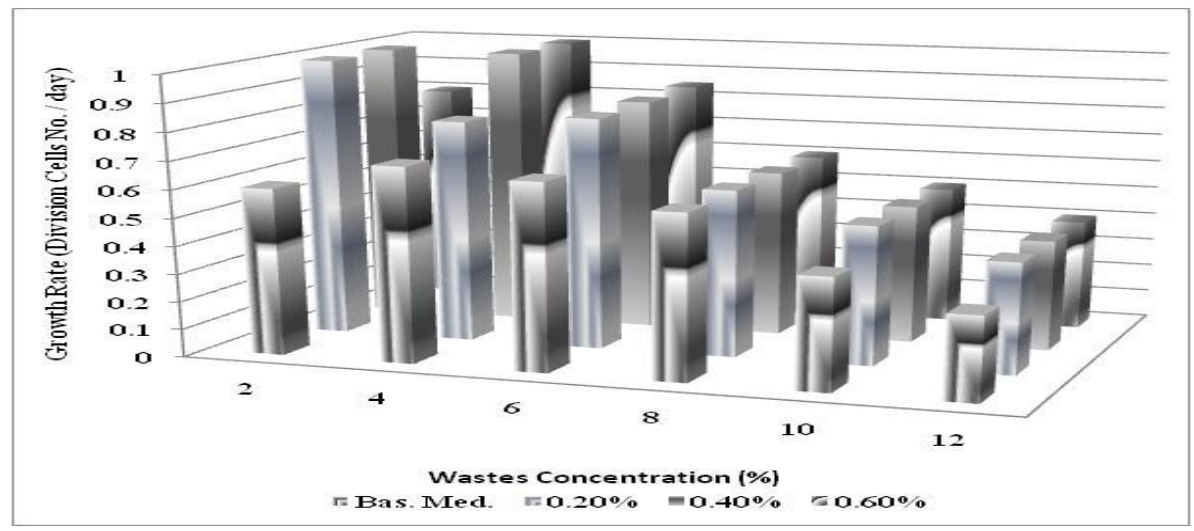

Figure (5): Growth rate of Scenedesmus dimorphus grown on Bold's basal medium and different concentration of poultry manure under different incubation periods

The results obtained by El-Fouly et al., (1984) showed that the maximum growth rate of Scenedesmus dimorphus of optimum concentration of sludge was achieved after 9 days. The contents of chlorophyll a were extracted at different temperature, from cultures supplied with different wasted (Fig.6).

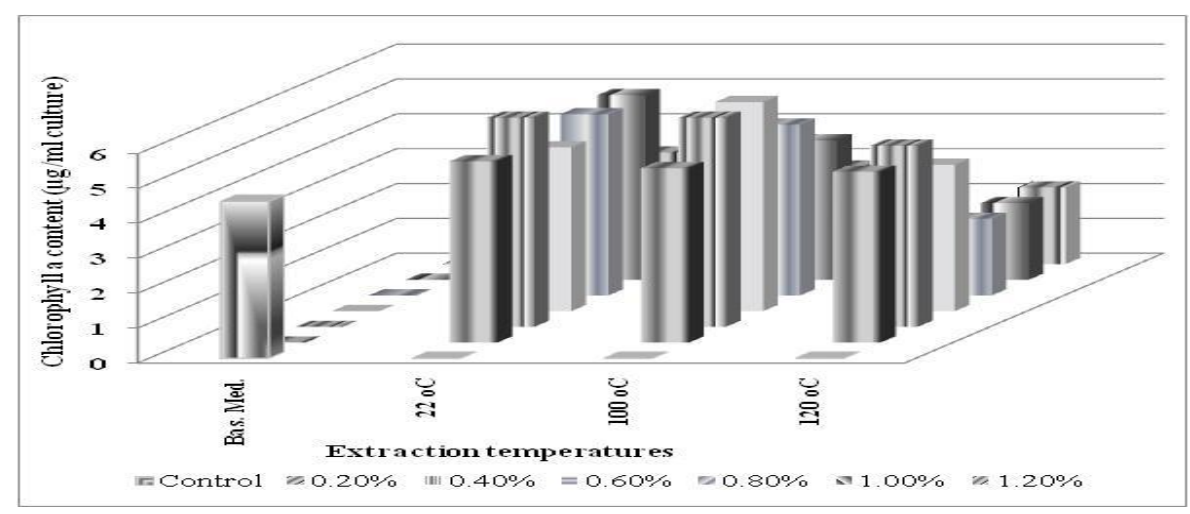

Figure (6): Chlorophyll (a) content of Scenedesmus dimorphus grown on Bold's basal medium and different concentration of poultry manure extracted at different temperatures 
The results varied according to the concentration of poultry manure and to the extraction temperature. Concerning evaluation of Scenedesmus dimorphus protein obtained in the present work, the comparative analysis of Chlorella (Payer et al., 2001). The FAO reference protein (FAO, 1983) is presented in Table (3) and Fig. (7). The results showed that the chemical score and the concentration of all amino acids in the protein of Scenedesmus dimorphus grown on poultry manure extract were higher than that of the algae grown on the medium. Also, the content of lysine the most important amino acid in Scenedesmus dimorphus grown on poultry manure extract was the highest when compared to that reported in Chlorella, Spirullina and even in FAO reference.

Table (3): Amino acids composition and chemical score of the protein of Scenedesmus dimorphus on Bold's basal medium (B.B.M.) and $0.4 \%$ water extract of poultry manure

\begin{tabular}{|l|c|c|c|c|c|}
\hline \multirow{2}{*}{ Amino acids } & \multicolumn{5}{|c|}{ Concentration (g/100 g protein) } \\
\cline { 2 - 6 } & $1 *$ & $2 *$ & $3 *$ & $4 *$ & FAO \\
\hline Aspartic acid & 1.09 & 2.40 & 8.20 & 10.10 & -- \\
Threonine & -- & -- & 3.90 & 5.52 & 4.0 \\
Serine & -- & -- & 2.7 & 4.35 & --- \\
Glutamic acid & 9.13 & 9.52 & 9.9 & 10.1 & --- \\
Proline & 0.95 & 1.35 & 2.8 & 6.74 & --- \\
Glycine & 1.46 & 2.7 & 4.4 & 5.7 & --- \\
Alanine & 2.19 & 7.7 & 6.03 & 7.15 & --- \\
Cysteine & 0.44 & 0.45 & 0.38 & 0.59 & --- \\
Valine & 0.7 & 1.61 & 3.9 & 2.47 & 5.0 \\
Methionine & 0.59 & 1.66 & 1.28 & 1.55 & 3.5 \\
Isoleucine & 1.13 & 2.21 & 3.74 & 5.61 & 4.0 \\
Leucine & 0.64 & 2.15 & 6.75 & 7.12 & 7.0 \\
Tyrosine & 1.15 & 2.58 & 5.8 & 6.65 & --- \\
Phenylalanine & 0.5 & 1.38 & 2.05 & 4.62 & 6.0 \\
Histidine & 1.45 & 1.2 & 1.4 & 2.0 & --- \\
Lysine & 1.85 & 1.91 & 4.17 & 5.03 & 5.5 \\
Arginine & 4.24 & 4.14 & 4.32 & 5.20 & --- \\
Chemical score & --- & --- & 47.4 & 61.1 & 100 \\
\hline
\end{tabular}

$1^{*}=$ Total free amino acids of Scenedesmus dimorphus grown on Bold's basal medium.

$2 *=$ Total free amino acids of Scenedesmus dimorphus grown on poultry manure extract.

$3^{*}=$ Bounded amino acids of Scenedesmus dimorphus grown on Bold's basal medium.

$4^{*}=$ Bounded amino acids of Scenedesmus dimorphus grown on poultry manure extract. 


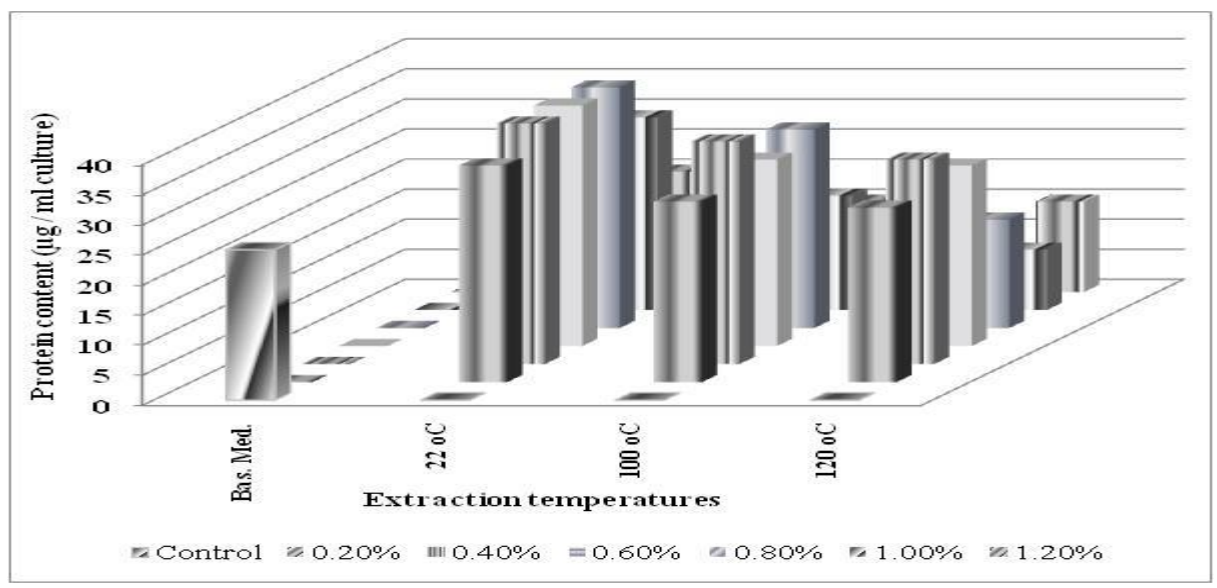

Figure (7): Protein content of Scenedesmus dimorphus grown on Bold's basal medium and different concentration of poultry manure extracted at different temperatures

Protein-tryptophan was not detected because it was destroyed during acid hydrolysis of algal protein (Dam et al., 2002). Regarding, the results of nucleic acids determination (Fig. 8), Scenedesmus dimorphus cells grown on Bold's basal medium contained higher concentrations of nucleic acids than that of cells grown on $0.4 \%$ poultry manure at both $22^{\circ} \mathrm{C}$ and $120^{\circ} \mathrm{C}$. From the previously given results, the nucleic acids per cent in relation to the algal dry weight (Fig. 9) was found to be of minimum value in the algal cells grown on $0.4 \%$ poultry manure (regardless higher concentration which produce lower algal growth) water extract prepared at $22^{\circ} \mathrm{C}$.

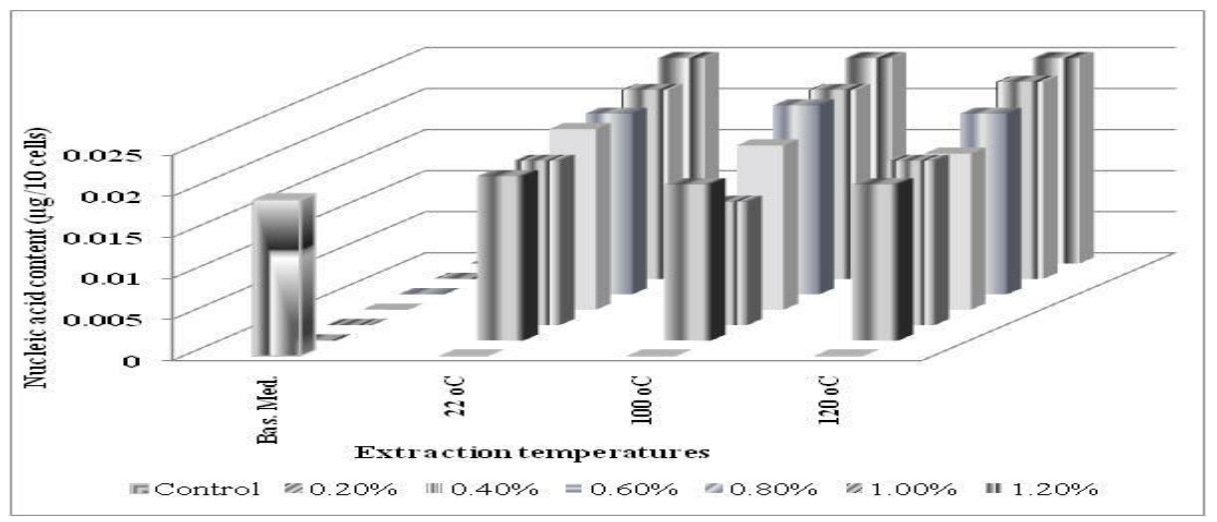

Figure (8): Nucleic acids content of Scenedesmus dimorphus grown on Bold's basal medium and different concentration of poultry manure extracted at different temperatures 


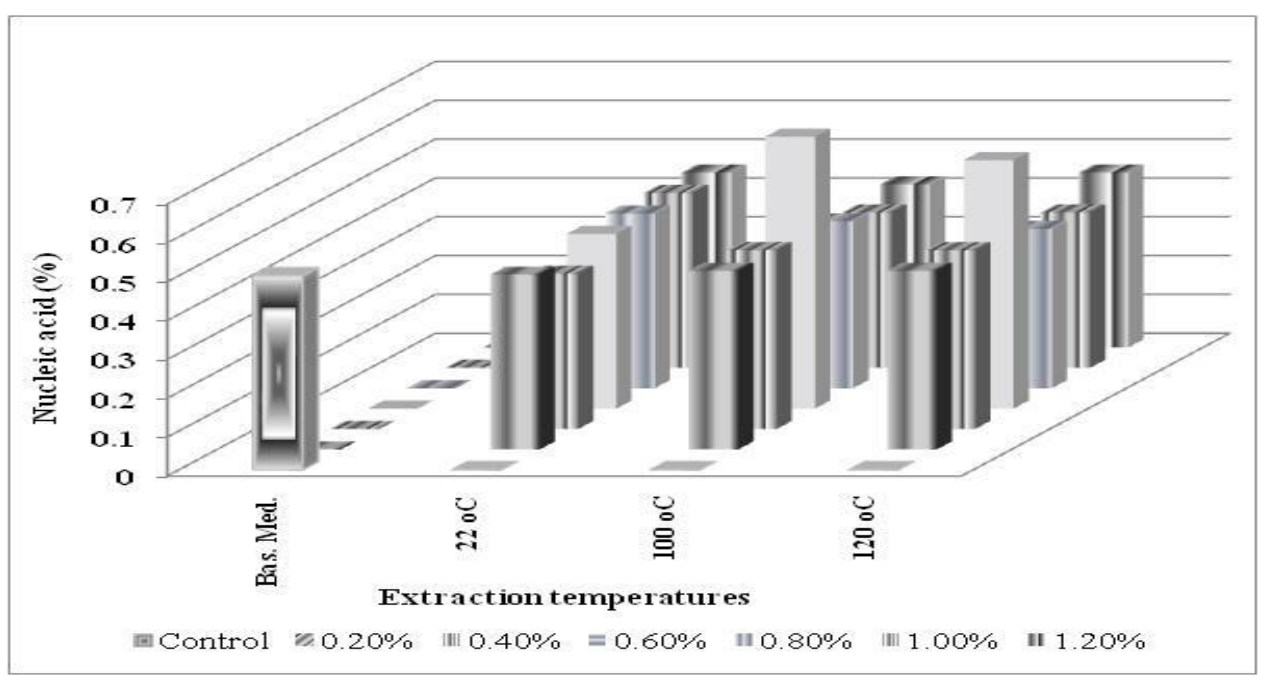

Figure (9): Nucleic acids percent of Scenedesmus dimorphus grown on Bold's basal medium and different concentration of poultry manure extracted at different temperatures

A constant worry in the utilization of microbial cells as food or feed may be refered to their high nucleic acids content. However, algae which were used as unicellular protein (such as Chlorella, Spirullina and Scenedesmus) contain definitely lower total nucleic acids contents than bacteria and yeasts (Wang et al., 2005). In accordance with this, Data reveled that Scenedesmus dimorphus cells grown on poultry manure extracts contained $0.22 \%$ - 34\% nucleic acids while that grown on B.B.M. contained $0.42 \%$ on dry weight basis. Considering that Scenedesmus has autotrophic, mixotrophic and heterotrophic modes of nutrition (Gonzalez et al., 2001), the results (Table 4) indicated that Scenedesmus dimorphus absorbed about $82 \%$ of the free amino acids and about $15 \%$ of water soluble carbohydrates.

Table (4): Utilization of some constituents of poultry manure by Scenedesmus dimorphus

\begin{tabular}{|l|c|c|c|}
\hline \multicolumn{1}{|c|}{ Constitutes } & $\begin{array}{c}\text { Control } \\
\text { medium }\end{array}$ & $\begin{array}{c}\text { Inoculated } \\
\text { medium }\end{array}$ & Consumption\% \\
\hline Final pH & 7.96 & 8.95 & -- \\
Number of cells $\times 10^{6} / \mathrm{ml}$ & - & 12.02 & -- \\
Total soluble carbohydrates & 40.2 & 34 & 15.4 \\
(p.p.m) (p.p.m) & 5.7 & 4.9 & 14.0 \\
Nitrate & 4.8 & 3.1 & 35.4 \\
Free ammonia (p.p.m) & 10.5 & 1.9 & $\mathbf{8 1 . 9}$ \\
Free amino acids (p.p.m) & & & \\
\hline
\end{tabular}

Egyptian J. of Phycol. Vol. 9, 2008

- 206 - 
Also the results indicated that Scenedesmus dimorphus absorbed about $35 \%$ of free ammonia and about $14 \%$ of nitrate. This result coincided with that reported by Molina et al., (2007) where they observed that there is general nutritional performance among fresh-water microalgae for ammonia followed by nitrate.

\section{\% Sulphur amino acids in sample protein \\ Chemical score $=\longrightarrow$ X 100}

In conclusion, the present study showed that poultry manure can be used as a potential growth medium for mass production of highly nutritive Scenedesmus dimorphus as a good source of protein.

\section{Acknowledgments}

The candidate wishes to express her deep gratitude and my deep thanks to Prof. Dr. Mohamed M. El-Fouly, Department of Botany, National Research Center, Dokki, Cairo, Egypt, and would like to thank Prof. Dr. Gamal El-Naggar, for his great help and co-supervision the whole work with continuous support, World Fish Center, Regional Center for Africa and West Asia, Abbassa, AbuHammad, Sharkia, Egypt.

\section{References}

Allen, E. J. and Nelson, E. W. (1974). On the artificial culture of marine plankton organisms. J. Mar. Biol. Assoc., 8:421.

Allen, M. D. B. and Garret, M. K. (1977). Bacterial changes occurring during the culture of algae in the liquid phase of animal slurry. J. Appl. Bacteriol.; 42: 27-43.

American Public Health Association (APHA) (1985). Standard methods for the examination of water and wastewater, edition American Public Health Association, Washington, D. C., USA.

Association of Official Analytical Chemists (A.O.A.C.) (1995). Official Methods of Analysis Association of Official Analytical Chemists. Edit., KHL rich. Arlington Vargenia, USA.

Badawy, Tartiel E. M. (2005). Physiological studies on some green algae. Ph.D. Thesis, Faculty of Agriculture, Cairo University. Egypt.

Becker, E. W. (1987). Biotechnology and exploitation of the green alga Scenedesmus obliquus in India. Biomass, 4: 11-19.

Becker, E. W. (1994). Microalgae, Biotechnology and Microbiology. Cambridge Univ. Press, pp. 9-39.

Benemann, J. R. (1992). Microalgae aquaculture feeds. Environmental J. Appl. Phycol., 4: 233-245. 
Bischoff, H . W. and Bold, H. C. (1963). Phycological studies. 4 some soil algae from Erchanted rock and related algal species. Univ. Texas, (8): 32-36.

Dam, R.; Lee, S. K.; Fry, P. C. and Fox, H. M. (2002). Utilization of algae as a protein source for humans. J. Nutr., 86:376.

De Pauw, N.; Morales, J. and Persoone, G. (1998): Mass culture of microalgae in aquaculture systems, Hydrobiologia, 116/ 117:121-134.

El-Fouly, M. M.; Abdalla, F. E. and Saleh, A. M. (1979). Studies on out-door mass culture of green alga Chlorella vulgaris.Effect of nitrogen efficiency in growth medium. Al-Azhar Agric.Bull., 22: 1-14.

El-Fouly, M. M.; Abdalla, F.E.; Saleh, A. M.; Shaheen, A. B. and El-Baz, F.K. (1984). Technological and biochemical studies on mass production of algae in Egypt. Algological Studies, 37:461.

El-Fouly, M. M.; Soeder, C. J.; Mohn, F. H. and Greoneweg, J. (1998). Open door mass production, chemical composition and biological evaluation of different algal species. Bull. Egypt, 2: 149-165.

FAO (1983). Compilation of legal limits for hazardous substances in fish and fishery products. FAO Fishery Circular No. 464.

Fathy, A. N. and Seyam M. S. (1989). Evaluation of some inorganic nutrients limiting the phytoplankton growth in River Nile using enrichment media M. Sc. Thesis Assiut Univ., pp. 121. Egypt.

Flaak, A. R. and Epifanio, C. E. (1978). Dietary protein levels and growth of the oyster Crassostrea virginica. Mar. Biol., 45: 157-164.

Gonzalez, L. E.; Canizares, R. O. and Baena, S. (2001). Efficiency of ammonia and phosphorus removal from a Colombian agroindustrial wastewater by the microalgae Chlorella vulgaris and Scenedesmus dimorphus. Environmental Biotechnology-Technology, 3: 259-262.

Molina, E.; Martinez, E.; Sanchez, S.; Garcia, F. and Contreras, A. (2007). The influence of flow rate and the composition of supplied $\mathrm{CO}_{2}$. Air mixture on discontinues growth. Microbiol. Biotechnol., 34: 103-107.

Morse, M. L. and Carter, C. F. (1969). The synthesis of nucleic acid in cultures of Escherchia coli strains B and B\R. J. Bacteriol., 58:317.

Payer, H. D.; Chiemvichak, Y.; Hosakul, K. and Kongpanich, J. (2001). Temperature as an important climatic factor during mass production of microalgae. Algae Biomass. Elsevier/North-Holland Biomedical Press, New York., USA., pp. 389-399.

Persoone, G.; Morales, F. and Garrcia, D. (2002). Mass culture of algae bottleneck in the nursery culturing of molluscs. Algae biomass. Texas, 5: 82-86.

Saleh, A. M., Abdalla, F. E. and El - Fouly, M. M. (1979). Studies on outdoor mass-culture of green alga. Seasonal variation of growth and crude Protein content. Al-Azhar Univ. Press. Cairo.

Vollenweider, S. K. (1969). Method for determination of Chlorophyll (a) in microplants and phosphoproteins in algae. I. Bid., Chem., 161:181. 
Wang, Q. L.; Liu, Y. D.; Shen, Y.W.; Jin, C.Y. and Zhu, J. M. (2005). Studies on mixed mass cultivation of Anabaena spp. (nitrogen-fixing blue-green algae) on a large scale. Hydrobiol. Acad. Sinica, China. 3: 221-228.

Zaret, T. M.; Devol, A. H. and Carter, A. D. (2001). Nutrient addition experiment in Lago Jacaretinga, Handbook of phycological methods. Cambridge University Press, London. pp. 69-85.

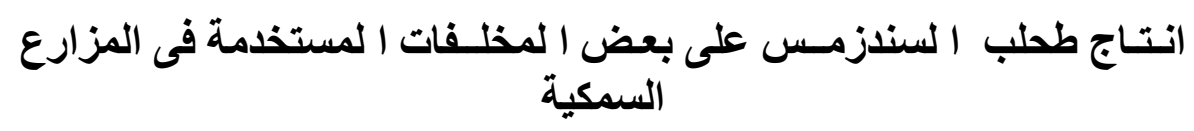

$$
\begin{aligned}
& \text { ترتيل السيد محمد بدوى }
\end{aligned}
$$

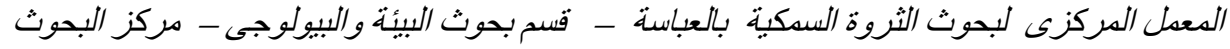

$$
\begin{aligned}
& \text { الزراعية - وزارة الزراعة - الدقى - مصر. }
\end{aligned}
$$

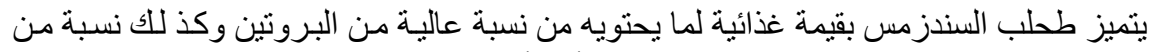

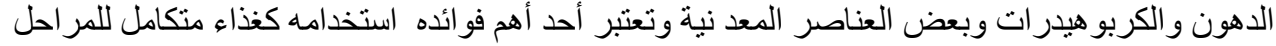

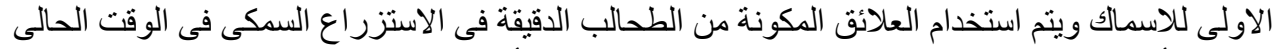

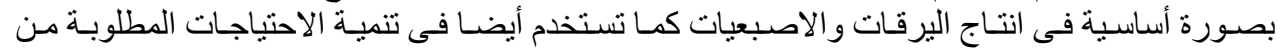

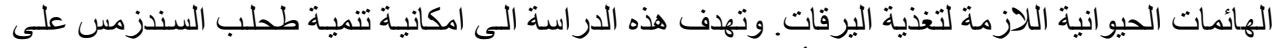

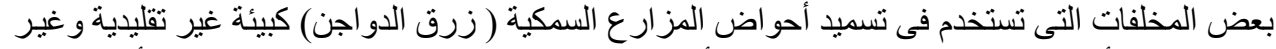

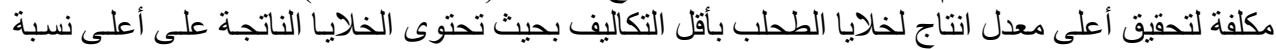

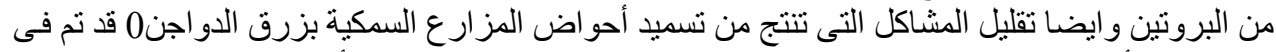

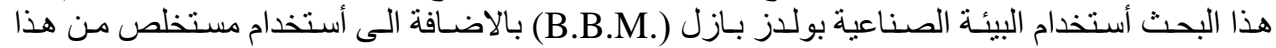

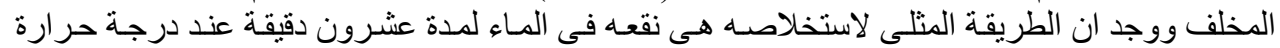

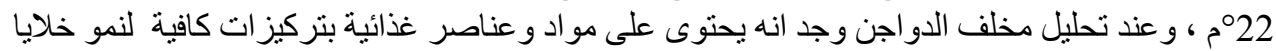

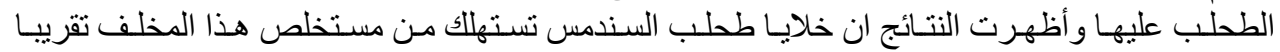

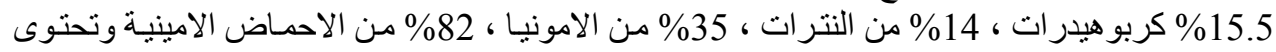

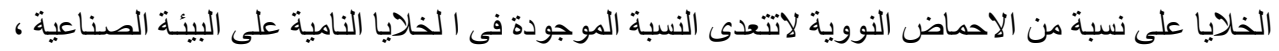

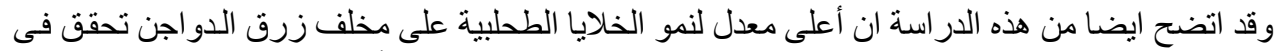

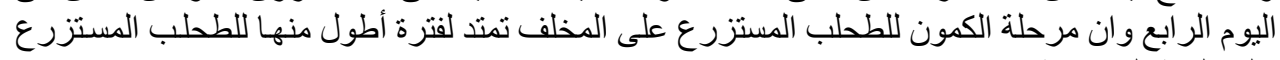

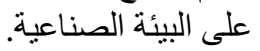

